\title{
India and management of COVID-19: A case study on published guidelines
}

\author{
Rohit Kumar ${ }^{1}$, Ankit Mittal ${ }^{1}$, Shreya Das Adhikari ${ }^{2}$, Eram Afroz ${ }^{1}$, Nitin Gupta ${ }^{3, *}$ \\ ${ }^{1}$ Department of Medicine, All India Institute of Medical Sciences, New Delhi, India; \\ ${ }^{2}$ Department of Anaesthesiology, Kasturba Medical College, Manipal Academy of Higher Education, Manipal, Karnataka, India; \\ ${ }^{3}$ Department of Infectious Diseases, Kasturba Medical College, Manipal, Manipal Academy of Higher Education, Manipal, Karnataka, India.
}

\begin{abstract}
SUMMARY In the face of the ongoing pandemic, the primary care physicians in India are dealing not only with an increased number of patients but are also facing difficulties in the management of complex critically ill patients. To guide the management plans of primary care physicians, several guidelines have been published by the central and state health bodies. In such a situation, an updated and unifying state, national and international guidelines based on critical analysis and appraisal of evolving data is the need of the hour. In this review, we critically analysed the current existing guidelines that have been formulated within India in light of recent evidence.
\end{abstract}

Keywords Coronavirus disease 2019, SARS-CoV-2, antiviral

\section{Introduction}

India's healthcare sector was on its knees during the second wave due to the high number of Coronavirus disease-2019 (COVID-19) cases. Besides the shortage of hospital beds, oxygen supply, and medications highlighted in the news reports, primary care physicians all over the country were dealing with increasingly complex and critically ill patients. With new research papers getting published every day, it is incredibly challenging for physicians to keep abreast with the latest evidence. As a result, most physicians resort to the clinical management guidelines published by competent authorities. The problem lies with the number of different guidelines (state, national, international) that differ on the critical aspects of management. For this commentary, the websites of the Infectious disease Society of America (IDSA), World Health Organisation (WHO), and health bodies of central/state governments of India were searched for the last available guidelines on the management of COVID-19 as of 31.05.2021. Apart from the national guidelines, the guidelines from various states were available. While most of the states endorsed the national management protocol; the states of Goa (GA), Jharkhand (JH), Karnataka (KA), Kerala (KL), Madhya Pradesh (MP), Maharashtra (MH), Meghalaya (MG), Tamil Nadu (TN), and West Bengal (WB) had their management guidelines. Last year, we published a comprehensive review pointing to the lack of congruency between these guidelines (1).
Since then, the guidelines have been revised, but the lack of congruency continue to exist. This review aims to examine the existing guidelines for congruence and critically analyse them in light of current evidence.

The definitions for categorising the severity of COVID-19 varied with guidelines. For uniformity, the spectrum of COVID-19 has been categorised into mild, moderate and severe in this review. The multiple definitions for these categories used in the guidelines have been summarised in Table 1. The recommendations of the guidelines have been tabulated in Table 2. The current evidence on the utility of drugs and therapeutics of COVID-19 has been summarised in Table 3.

\section{Hydroxychloroquine (HCQ)}

HCQ was initially recommended based on small nonrandomised studies, but later studies showed no effect of HCQ on mortality $(2,3)$. However, it was evident from the results of the SOLIDARITY trial that the use of HCQ is not associated with any decrease in mortality, the requirement of ventilation and hospital stay $(4,5)$. The drug was also suggested for postexposure prophylaxis by some guidelines, but a randomised trial found that HCQ did not prevent illness when initiated within four days of exposure (6). HCQ also failed to show any reduction in symptom severity in patients of COVID-19 when given early in the course (7). Therefore, the WHO and IDSA have recommended 
Table 1. Classification scheme of COVID-19 and definitions used by various guidelines

\begin{tabular}{|c|c|c|c|}
\hline Guidelines & Mild & Moderate & Severe \\
\hline WHO & $\begin{array}{l}\text { Symptoms without evidence of viral } \\
\text { pneumonia or hypoxia. }\end{array}$ & $\begin{array}{l}\text { Pneumonia }+ \text { no signs of severe } \\
\text { pneumonia }+\mathrm{SpO} 2 \geq 90 \%\end{array}$ & $\begin{array}{l}\text { Pneumonia }+\mathrm{RR}>30 \text { per minute; severe } \\
\text { respiratory distress; or } \mathrm{SpO} 2<90 \%\end{array}$ \\
\hline IDSA & Non-severe illness - patient with $\mathrm{SpO} 2>94^{\circ}$ & $\%$; not requiring supplemental oxygen & $\mathrm{SpO} 2 \leq 94 \%$ \\
\hline India & No dyspnoea and Spo $2>94 \%$ & $\begin{array}{l}\text { Pneumonia }+\mathrm{SpO} 290 \text { to } \leq 93 \%, \mathrm{RR}> \\
24 \text { per minute }\end{array}$ & $\begin{array}{l}\text { Pneumonia }+\mathrm{RR}>30 \text { per minute, severe } \\
\text { respiratory distress, } \mathrm{SpO} 2<90 \%\end{array}$ \\
\hline Jharkhand & Non critically ill + hemodynamically stable & \multicolumn{2}{|c|}{$\begin{array}{l}\mathrm{RR}>30 \text { per minute, } \mathrm{SpO} 2<90 \% \text {, altered sensorium, oliguria, high } \\
\text { lactate, bilateral radiograph opacities }\end{array}$} \\
\hline Kerala & $\begin{array}{l}\text { No breathlessness or Hypoxia, } \mathrm{RR}<24 \text { per } \\
\text { minute, } \mathrm{SpO} 2>94 \%\end{array}$ & RR - 24-29 per minute, $\mathrm{SpO} 2-91-94 \%$ & $\mathrm{RR}>30$ per minute, $\mathrm{SpO} 2<90 \%$ \\
\hline Madhya Pradesh & No dyspnoea, $\mathrm{SpO} 2>94 \%, \mathrm{RR}<16 / \mathrm{min}$ & Pneumonia + SpO2 90 - 94\% & $\begin{array}{l}\text { Pneumonia }+ \text { severe respiratory distress, } \\
\mathrm{SpO} 2<90 \%\end{array}$ \\
\hline Maharashtra & $\begin{array}{l}\text { A - asymptomatic, B - Symptomatic } \\
\text { without comorbidity, C - Symptomatic with } \\
\text { comorbidity - obesity, age > } 60 \text { years, DM, } \\
\text { hypertension/IHD, chronic lung disease, } \\
\text { immunosuppressed, CKD }\end{array}$ & $\begin{array}{l}\text { Pneumonia }+\mathrm{SpO} 2: 90-94 \%, \mathrm{RR}>24 \\
\text { per minute. }\end{array}$ & $\begin{array}{l}\text { Pneumonia }+\mathrm{RR}>30 \text { per minute, severe } \\
\text { respiratory distress, } \mathrm{SpO} 2<90 \%\end{array}$ \\
\hline Meghalaya & $\begin{array}{l}\text { Category A - asymptomatic } \\
\text { Category B - Symptomatic with no signs of } \\
\text { severe pneumonia; RR - } 16-24 \text { per minute, } \\
\text { Spo } 2>94 \%\end{array}$ & \multicolumn{2}{|c|}{$\begin{array}{l}\text { Category } \mathrm{C} \text { (Severe) }-\mathrm{RR}>24 \text { per minute, } \mathrm{SpO} 2<94 \% \\
\text { Category D (Critical) - RR }>30 \text { per minute, } \mathrm{SpO} 2<90 \%\end{array}$} \\
\hline Tamil Nadu & $\mathrm{RR}<24$ per minute, $\mathrm{Spo} 2>94 \%$ & RR- 24-30 per minute, $\mathrm{SpO} 2-90-94 \%$ & $\mathrm{RR}>30$ per minute, $\mathrm{SpO} 2<90 \%$ \\
\hline Goa & No dyspnoea, $\mathrm{SpO} 2>93 \%$ & $\begin{array}{l}\text { Pneumonia }+\mathrm{SpO} 290 \text { to } \leq 93 \%, \mathrm{RR}> \\
24 \text { per minute }\end{array}$ & $\begin{array}{l}\text { Pneumonia }+\mathrm{RR}>30 \text { per minute, severe } \\
\text { respiratory distress, } \mathrm{SpO} 2<90 \%\end{array}$ \\
\hline West Bengal & Symptoms without shortness of breath & $\begin{array}{l}\mathrm{RR}>24 \text { per minute; } \mathrm{SpO} 2<94 \% \text {; } \\
\text { altered sensorium drowsiness/confusion/ } \\
\text { stupor; infiltrates on Chest X-ray; } \\
\text { altered liver and renal function tests }\end{array}$ & $\begin{array}{l}\text { Moderate Disease + ARDS, sepsis, septic } \\
\text { shock }\end{array}$ \\
\hline
\end{tabular}

Abbreviation: WHO, World Health Organisation; IDSA, Infectious disease Society of America; RR, respiratory rate; SpO2, oxygen saturation; DM, diabetes mellitus; IHD, ischaemic heart disease; CKD, chronic kidney disease; ARDS, acute respiratory distress syndrome.

against the use of HCQ in COVID-19 in their latest guidelines. While HCQ is no more recommended in national guidelines and state guidelines of KL, TN \& WB, several state guidelines ( $\mathrm{JH}, \mathrm{MG}, \mathrm{MH}, \mathrm{MP}, \mathrm{KA})$ continue to recommend it.

\section{Ivermectin}

Ivermectin, an anti-parasitic drug, has also found a place in the treatment of COVID-19 since the start of the pandemic. A pilot randomised trial reported a reduction in self-reported symptoms using ivermectin within 72 hours of the onset of symptoms (8). Another study found reduced time to negativity with ivermectin (9). However, in two randomised, double-blind placebocontrolled trials, on mild (Lopez Medina et al.) and severe (Galan et al.) patients, there was no improvement in clinical outcomes with ivermectin $(10,11)$. Ivermectin use has been incorporated in some guidelines based on a meta-analysis of 18 studies showing decreased mortality with ivermectin (12). However, most of these studies had a very high risk of bias and one of the study from the meta-analysis has been retracted. In the absence of new studies demonstrating absolute benefit, ivermectin has been removed from the national guidelines, but some states still recommend it (JH, KL, MH, TN, GA, WB).

\section{Favipiravir}

Favipiravir is a selective and potent inhibitor of influenza RNA polymerase. An initial, before-after, comparative study found a shorter median time to viral clearance and significant improvement in radiological findings (13). It was initially postulated that early administration of favipiravir might be more useful. Still, a study showed no difference in early $v s$. late administration of favipiravir in asymptomatic or mild COVID19 illness (14). In the open labelled trial from India, the viral clearance time was not significant, but the subjective clinical cure was faster in those who received favipiravir (15). However, subsequent studies by Dabbous et al., Solaymani-Dodaran et al., and Khamis et al. did not show any significant clinical benefit with favipiravir (16-18). The WHO and IDSA do not make any recommendation on the use of favipiravir in COVID-19. However, based on small studies showing limited benefit, favipiravir is recommended in some state guidelines ( $\mathrm{KL}$ and $\mathrm{MH}$ ). 


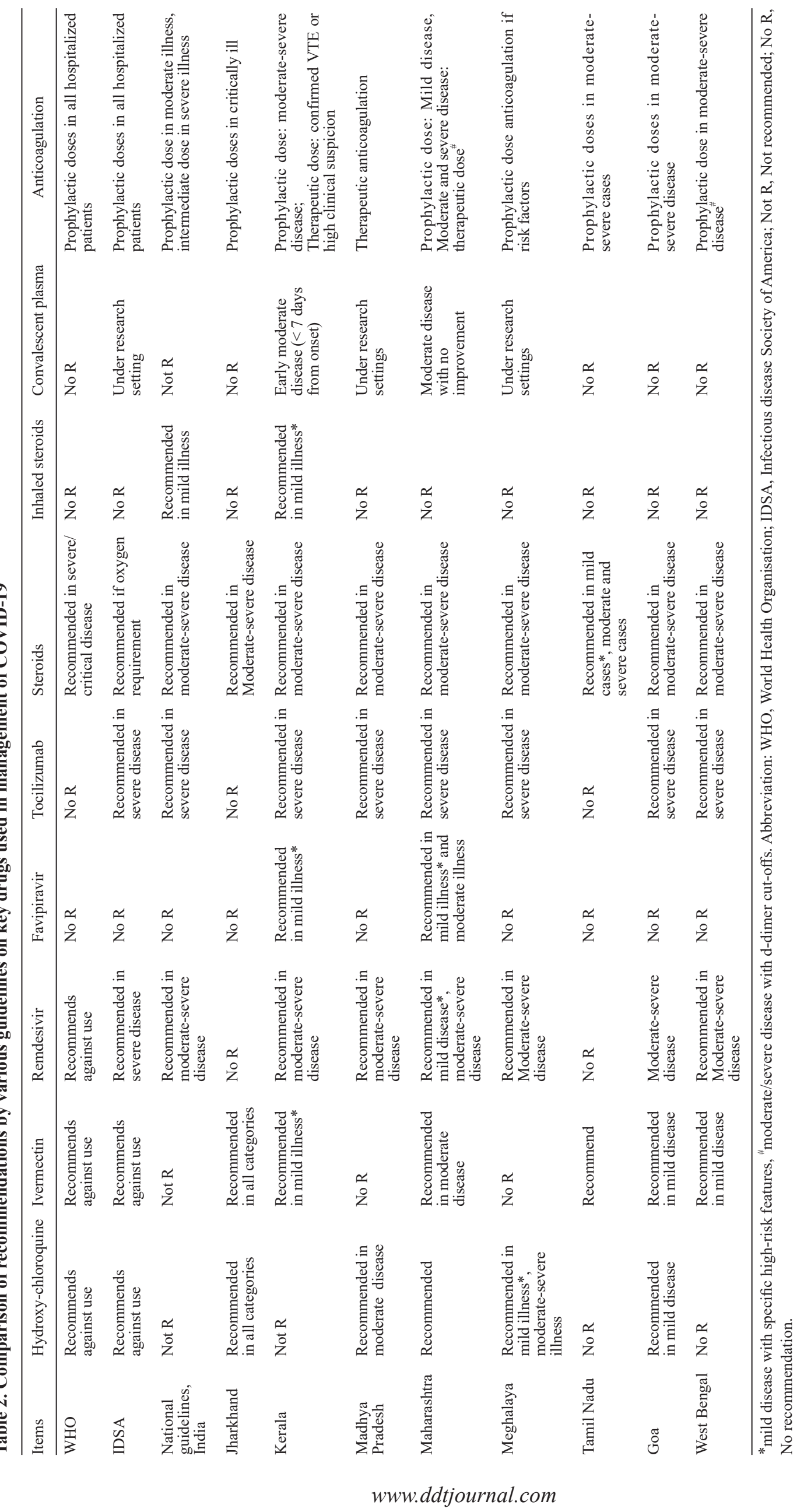


Table 3. Summary of studies of pharmaceuticals used for the treatment of COVID-19

\begin{tabular}{|c|c|c|c|c|c|c|}
\hline Study & $\mathrm{N}$ & Type of study & Severity & Study arms & Results & Ref. \\
\hline \multicolumn{7}{|c|}{ Hydroxychloroquine (HCQ) with/without azithromycin (A) } \\
\hline Geleris et al. & 1376 & Retrospective & All severity & $\begin{array}{l}\text { HCQ- } 59 \% \\
\text { No HCQ-41\% }\end{array}$ & $\begin{array}{l}\text { No association between HCQ use and } \\
\text { decrease in intubation or death }\end{array}$ & (2) \\
\hline Rosenberg et al. & 1438 & Retrospective & All severity & $\begin{array}{l}\text { HCQ- } 51 \% \\
\text { HCQ+A-19\% } \\
\text { A- } 15 \% \\
\text { Neither- } 15 \%\end{array}$ & $\begin{array}{l}\text { Treatment with either drug not associated } \\
\text { with improvement in mortality }\end{array}$ & (3) \\
\hline RECOVERY & 11,197 & Open RCT & Hospitalised patients & $\begin{array}{l}\text { HCQ-1561 } \\
\text { Usual care-3155 }\end{array}$ & $\begin{array}{l}\text { Treatment with HCQS was not associated } \\
\text { with a reduction in mortality }\end{array}$ & (4) \\
\hline SOLIDARITY & 1860 & Open RCT & $\begin{array}{l}\text { Hospitalised adults } \\
\text { (All severity) }\end{array}$ & $\begin{array}{l}\text { HCQ-954 } \\
\text { No HCQ-906 }\end{array}$ & $\begin{array}{l}\text { No decrease in mortality, a requirement of } \\
\text { ventilation and hospital stay }\end{array}$ & $(5)$ \\
\hline Boulware et al. & 821 & $\begin{array}{l}\text { Double blind } \\
\text { placebo RCT }\end{array}$ & $\begin{array}{l}\text { Exposure to case } \\
\text { within four days }\end{array}$ & $\begin{array}{l}\text { HCQ- } 50 \% \\
\text { Placebo- } 50 \%\end{array}$ & $\begin{array}{l}\text { HCQ did not prevent infection when used } \\
\text { as a post-exposure prophylaxis }\end{array}$ & $(6)$ \\
\hline Skipper et al. & 491 & $\begin{array}{l}\text { Double blind } \\
\text { placebo RCT }\end{array}$ & $\begin{array}{l}\text { Symptomatic } \\
\text { non-hospitalised }\end{array}$ & $\begin{array}{l}\text { HCQ- } 50 \% \\
\text { Pacebo- } 50 \%\end{array}$ & HCQ did not reduce symptom severity & $(7)$ \\
\hline \multicolumn{7}{|l|}{ Ivermectin (IVM) } \\
\hline Chaccour et al. & 24 & $\begin{array}{l}\text { Double blind } \\
\text { placebo RCT }\end{array}$ & Mild & $\begin{array}{l}\text { IVM-12 } \\
\text { Placebo-12 }\end{array}$ & No difference in Day 7 viral load & $(8)$ \\
\hline Babalola et al & 62 & $\begin{array}{l}\text { Double blind } \\
\text { placebo RCT }\end{array}$ & Mild & $\begin{array}{l}\text { IVM-6mg-21 } \\
\text { IVM-12 mg-21 } \\
\mathrm{LPV} / \mathrm{r}-20\end{array}$ & $\begin{array}{l}\text { Time to negativity was lesser in IVM } \\
\text { (dose-dependant) }\end{array}$ & (9) \\
\hline Galan et al. & 168 & $\begin{array}{l}\text { Double blind } \\
\text { RCT }\end{array}$ & Severe & $\begin{array}{l}\mathrm{HCQ}-54 \\
\text { CQ-61 } \\
\text { IVM-53 }\end{array}$ & $\begin{array}{l}\text { No difference in requirement of ICU } \\
\text { admission or mortality }\end{array}$ & $(10)$ \\
\hline Lopez Medina et al. & 400 & $\begin{array}{l}\text { Double blind } \\
\text { placebo RCT }\end{array}$ & $\begin{array}{l}\text { Mild, less than } \\
\text { seven days }\end{array}$ & $\begin{array}{l}\text { IVM-200 } \\
\text { Placebo-200 }\end{array}$ & $\begin{array}{l}\text { No significant improvement in resolution } \\
\text { of symptoms }\end{array}$ & (11) \\
\hline \multicolumn{7}{|l|}{ Favipiravir $C T$} \\
\hline Cai et al. & 80 & Open non-RCT & Mild & $\begin{array}{l}\text { FPV-35 } \\
\mathrm{LPV} / \mathrm{r}-45\end{array}$ & $\begin{array}{l}\text { Shorter time to viral clearance with FPV. } \\
\text { Significant improvement in radiology more } \\
\text { common with FPV. }\end{array}$ & (13) \\
\hline Udwadia etal & 89 & Open RCT & Mild & $\begin{array}{l}\text { Early FPV (D1)-44 } \\
\text { Late FPV (D6)-45 }\end{array}$ & $\begin{array}{l}\text { No significant difference in viral clearance } \\
\text { in early } v \text { s late }\end{array}$ & (14) \\
\hline & 150 & Open RCT & Mild & $\begin{array}{l}\text { FPV-75 } \\
\text { SOC-75 }\end{array}$ & $\begin{array}{l}\text { Time to cessation of viral shedding- not } \\
\text { significantly different but faster clinical } \\
\text { cure }\end{array}$ & $(15)$ \\
\hline & 100 & Open RCT & Mild and Moderate & $\begin{array}{l}\text { FPV-50 } \\
\text { HCQ-50 }\end{array}$ & $\begin{array}{l}\text { Time to defervescence and time to } \\
\text { negativity not different }\end{array}$ & $(16)$ \\
\hline $\begin{array}{l}\text { Solaymani-dodaram } \\
\text { et al. }\end{array}$ & 380 & Open RCT & Moderate/severe & $\begin{array}{l}\text { FPV-193 } \\
\text { LPV/r-187 }\end{array}$ & $\begin{array}{l}\text { Mortality, requirement of intubation, ICU } \\
\text { admission, Duration of stay not different }\end{array}$ & $(17)$ \\
\hline Conderin (PDVU & 89 & Open RCT & Moderate/severe & $\begin{array}{l}\text { FPV-44 } \\
\text { HCQ-45 }\end{array}$ & $\begin{array}{l}\text { No significant difference in clinical } \\
\text { outcomes }\end{array}$ & $(18)$ \\
\hline Wang et al. & 237 & $\begin{array}{l}\text { Double blind } \\
\text { placebo RCT }\end{array}$ & Moderate/Severe & $\begin{array}{l}\text { RDV-67\% } \\
\text { Placebo-33\% }\end{array}$ & $\begin{array}{l}\text { RDV not associated with significant } \\
\text { clinical improvement }\end{array}$ & (19) \\
\hline $\begin{array}{l}\text { Beigel et al. } \\
\text { (ACTT1) }\end{array}$ & 1059 & $\begin{array}{l}\text { Double blind } \\
\text { placebo RCT }\end{array}$ & Pneumonia & $\begin{array}{l}\text { RDV-51\% } \\
\text { Placebo- } 49 \%\end{array}$ & RDV shortened the time to recovery & $(20)$ \\
\hline SOLIDARITY & 5451 & Open RCT & $\begin{array}{l}\text { Hospitalised } \\
\text { (All severity) }\end{array}$ & $\begin{array}{l}\text { RDV-2743 } \\
\text { No RDV-2708 }\end{array}$ & $\begin{array}{l}\text { No decrease in mortality, requirement of } \\
\text { ventilation and hospital stay }\end{array}$ & $(5)$ \\
\hline
\end{tabular}

Abbreviation: SOC, standard of care; ICU, Intensive Care Unit; Dexa, dexamethasone; MPS, methylprednisolone; hydrocort, hydrocortisone; ECMO, extracorporeal membrane oxygenation; RCT, randomised controlled trial; Open, Open-labelled, placebo- placebo controlled.

\section{Remdesivir}

Remdesivir is a nucleoside analogue, which acts by inhibiting the ribonucleic acid (RNA) dependent RNA polymerase. In a multi-centric placebo-controlled trial from China, remdesivir use was not associated with a difference in time to clinical improvement (19). Two of the most significant studies on the use of remdesivir showed contradictory results. In the ACTT-1 trial, remdesivir showed a faster time to recovery in patients with lung involvement (20). However, the results of the SOLIDARITY trial showed no significant benefit 
Table 3. Summary of studies of pharmaceuticals used for the treatment of COVID-19 (continued)

\begin{tabular}{|c|c|c|c|c|c|c|}
\hline Study & $\mathrm{N}$ & Type of study & Severity & Study arms & Results & Ref. \\
\hline \multicolumn{7}{|l|}{ Steroids } \\
\hline RECOVERY & 6,425 & Open RCT & Hospitalised & $\begin{array}{l}\text { Dexa-33\% } \\
\text { SOC-67\% }\end{array}$ & $\begin{array}{l}\text { Reduced mortality in those receiving } \\
\text { oxygen therapy or mechanical ventilation }\end{array}$ & $(21)$ \\
\hline Edalatifard et al. & 68 & Single arm & $\begin{array}{l}\text { Severe, hospitalised } \\
\text { patients }\end{array}$ & $\begin{array}{l}\text { MPS pulse-34 } \\
\text { SOC-34 }\end{array}$ & Significant improvement in survival time & (22) \\
\hline Tomazini et al. & 299 & Open RCT & $\begin{array}{l}\text { Moderate-severe } \\
\text { ARDS }\end{array}$ & $\begin{array}{l}\text { Dexa-151 } \\
\text { SOC-148 }\end{array}$ & Significant increase in ventilator-free days & (23) \\
\hline REMAP-CAP trial & 384 & Open RCT & Severe & $\begin{array}{l}\text { Hydrocort-283 } \\
\text { SOC-101 }\end{array}$ & No signifcant difference & (24) \\
\hline Tang et al. & 86 & $\begin{array}{l}\text { Single-blind, } \\
\text { RCT }\end{array}$ & Hospitalised & $\begin{array}{l}\text { MPS-43 } \\
\text { Control-43 }\end{array}$ & No significant difference & (25) \\
\hline Gudino et al. & 64 & Open RCT & $\begin{array}{l}\text { Moderate-severe } \\
\text { disease }\end{array}$ & $\begin{array}{l}\text { MPS-35 } \\
\text { SOC-26 }\end{array}$ & No significant difference & (26) \\
\hline \multicolumn{7}{|l|}{ Tocilizumab (Tcz) } \\
\hline Guaraldi et al. & 544 & Retrospective & Severe & $\begin{array}{l}\text { SOC-67\% } \\
\text { Tcz-33\% }\end{array}$ & $\begin{array}{l}\text { Tcz associated with reduced mortality and } \\
\text { mechanical ventilation }\end{array}$ & (30) \\
\hline Biran et al. & 764 & Retrospective & ICU patients & $\begin{array}{l}\text { SOC- } 73 \% \\
\text { Tcz- } 27 \%\end{array}$ & Tcz was associated with decreased mortality & $(31)$ \\
\hline Salama et al. & 389 & $\begin{array}{l}\text { Double blind } \\
\text { placebo RCT }\end{array}$ & Moderate/severe & $\begin{array}{l}\text { Tcz-249 } \\
\text { Placebo-128 }\end{array}$ & $\begin{array}{l}\text { Reduced likelihood of getting mechanically } \\
\text { ventilated; no benefit in overall survival }\end{array}$ & $(32)$ \\
\hline Soin et al. & 180 & Open RCT & $\begin{array}{l}\text { Moderate to severe } \\
\text { COVID19 }\end{array}$ & $\begin{array}{l}\text { Tcz-90 } \\
\text { SOC-90 }\end{array}$ & $\begin{array}{l}\text { tocilizumab did not provide additional } \\
\text { benefit }\end{array}$ & (33) \\
\hline RECOVERY & 1,350 & Open RCT & $\begin{array}{l}\text { Moderate } / \mathrm{severe} \\
\mathrm{CRP}>75 \mathrm{mg} / \mathrm{L}\end{array}$ & $\begin{array}{l}\text { Tcz-621 } \\
\text { SOC-729 }\end{array}$ & $\begin{array}{l}\text { Improved survival and other clinical } \\
\text { outcomes with tcz }\end{array}$ & (34) \\
\hline \multicolumn{7}{|c|}{ Convalescent Plasma (CP) } \\
\hline Xia et al. & 1,568 & Retrospective & Severe/critical & $\begin{array}{l}\text { CP-9\% } \\
\text { No CP-91\% }\end{array}$ & $\begin{array}{l}\text { Reduction in mortality and improvement of } \\
\text { clinical symptoms }\end{array}$ & $(35)$ \\
\hline Abolghasemi et al. & 189 & Open non-RCT & Moderate/severe & $\begin{array}{l}\text { CP-61\% } \\
\text { No CP-39\% }\end{array}$ & Decreased hospital stay and mortality & (36) \\
\hline Li et al. & 103 & Open RCT & $\begin{array}{l}\text { Severe/life- } \\
\text { threatening }\end{array}$ & $\begin{array}{l}\text { CP- } 50 \% \\
\text { No } \mathrm{CP}-50 \%\end{array}$ & $\begin{array}{l}\text { No significant improvement in time to } \\
\text { clinical improvement }\end{array}$ & $(37)$ \\
\hline PLACID trial & 464 & Open RCT & Moderate & $\begin{array}{l}\text { CP-235 } \\
\text { SOC-229 }\end{array}$ & $\begin{array}{l}\mathrm{CP} \text { not associated with a reduction in } \\
\text { progression or reduction of mortality }\end{array}$ & $(38)$ \\
\hline Libster et al. & 160 & $\begin{array}{l}\text { Double blind } \\
\text { placebo RCT }\end{array}$ & $\begin{array}{l}\text { Older adults within } \\
72 \text { hours of mild } \\
\text { disease }\end{array}$ & $\begin{array}{l}\text { CP with high } \\
\text { titre- } 80 \\
\text { Placebo- } 80\end{array}$ & $\begin{array}{l}\text { Early administration of high titre } \mathrm{CP} \\
\text { reduced disease progression }\end{array}$ & (39) \\
\hline $\begin{array}{l}\text { Abani et al. } \\
\text { (RECOVERY) }\end{array}$ & 11,558 & Open RCT & Hospitalised & $\begin{array}{l}\text { CP-5795 } \\
\text { SOC-5763 }\end{array}$ & $\mathrm{CP}$ does not decrease mortality & $(40)$ \\
\hline \multicolumn{7}{|l|}{ Inhaled Steroids } \\
\hline STOIC trial & 146 & Open RCT & Mild within 7 days & $\begin{array}{l}\text { Budesonide-73 } \\
\text { SOC-73 }\end{array}$ & $\begin{array}{l}\text { Early administration reduced the } \\
\text { requirement of urgent care }\end{array}$ & $(41)$ \\
\hline PRINCIPLE trial & 1,779 & Open RCT & $\begin{array}{l}\text { Mild within }<14 \\
\text { days }\end{array}$ & $\begin{array}{l}\text { Budesonide-751 } \\
\text { SOC-1028 }\end{array}$ & Time to clinical recovery shorter & (42) \\
\hline \multicolumn{7}{|l|}{ Anti-coagulation } \\
\hline INSPIRATION trial & 600 & Open RCT & ICU patients & $\begin{array}{l}\text { Intermediate-276 } \\
\text { Standard- } 286\end{array}$ & $\begin{array}{l}\text { No significant difference in the composite } \\
\text { outcome of thrombosis, treatment with } \\
\text { ECMO, or mortality }\end{array}$ & (43) \\
\hline ATTACC & 1,074 & Open RCT & Severe & $\begin{array}{l}\text { Therapeutic } \\
\text { dose- } 529 \\
\text { Standard } \\
\text { prophylaxis-545 }\end{array}$ & $\begin{array}{l}\text { No significant difference in organ-support } \\
\text { free days and survival }\end{array}$ & (44) \\
\hline ATTACC & 2,245 & Open RCT & $\begin{array}{l}\text { Hospitalized but } \\
\text { not critically ill }\end{array}$ & $\begin{array}{l}\text { Therapeutic } \\
\text { dose- } 1190 \\
\text { Standard } \\
\text { prophylaxis-1055 }\end{array}$ & Improved survival with therapeutic dose & (45) \\
\hline
\end{tabular}

Abbreviation: SOC, standard of care; ICU, Intensive Care Unit; Dexa, dexamethasone; MPS, methylprednisolone; hydrocort, hydrocortisone; ECMO, extracorporeal membrane oxygenation; RCT, randomised controlled trial; Open, Open-labelled, placebo- placebo controlled. 
with remdesivir (5). Based on available data, the WHO gave a conditional recommendation against remdesivir, but the IDSA recommends its use in severe COVID-19 cases. The national and state guidelines (KL, MH, MG and $\mathrm{WB}$ ) recommend its use in hospitalised, moderate to severe COVID-19 cases. Several parts of the country reported a shortage of remdesivir in the second wave. In addition, there were reports of patient attendants paying an excessive amount of money to procure this drug. It must be therefore emphasised that the drug has limited impact on improvement in mortality outcomes.

\section{Systemic steroids (oral/intravenous)}

In the RECOVERY trial, dexamethasone was found to help decrease 28-day mortality in patients requiring oxygen (21). Other large studies echoed the findings of the RECOVERY trial (22-24). The RECOVERY trial showed that the benefit of steroids was in patients who had $>7$ days of illness. Early use $(<7$ days $)$ of steroids was associated with worse outcomes. A study by Tang et al. showed that early use of steroids might prolong viral shedding (25). Despite the lack of evidence, national guidelines allow steroids in those without oxygen requirements but with illness (fever and cough) beyond seven days. TN state has also recommended the use of steroids in a sub-category of patients with mild illness. Overall, although the national and state guidelines are consistent with their recommendation on steroid use in moderatesevere cases, there is a lot of heterogeneity in dosing schedules. While some guidelines (IDSA, WHO, MG, MP) mention fixed-dose steroids, others recommend weight-based dosing. MP guidelines recommend the use of $500 \mathrm{mg}$ methylprednisolone pulse therapy in severe disease, which any other guideline has not endorsed. Except for a few studies with small sample size, steroids use in patients requiring oxygen is generally associated with improved outcomes (26). Increasing immunosuppression without forethought can be detrimental by increasing secondary infections and sepsis (27). This becomes more important as we see an unprecedented rise in COVID-19 associated mucormycosis cases. Steroids not only suppresses the immune system but also causes deranged blood sugar levels, both of which are important risk factors for the development of mucormycosis $(28,29)$.

\section{Tocilizumab}

Tocilizumab, an interleukin (IL)-6 receptor inhibitor, is an approved treatment for chimeric antigen receptor (CAR) T-cell therapy-related cytokine release syndrome. In severe COVID19, tocilizumab was postulated to decrease the cytokine surge and associated hyperinflammation, in severe illness, by blocking the site of IL-6. In a case-control study, including 544 patients of severe COVID19 pneumonia (RR > 30/min, Spo2 $<93 \%$ on room air) (30), the use of tocilizumab was associated with statistically significant benefit in reducing the need for ventilation or death. In another retrospective cohort study of 764 patients, tocilizumab in 210 patients was associated with reduced mortality (31). The first prospective data came from a multinational, multi-centric study of 389 patients, randomised in a 2:1 manner in tocilizumab and placebo groups, respectively (32). The use of tocilizumab in 249 patients reduced the likelihood of getting mechanically ventilated, but no benefit in overall survival was noted. In a trial from India including 180 patients (1:1 manner) in tocilizumab and standard of care groups, tocilizumab did not provide additional benefit (33). The results of the RECOVERY trial showed improved survival in those with saturation less than $93 \%$ and C-reactive protein $>75 \mathrm{mg} / \mathrm{L}(34)$. Whereas WHO has made no recommendation on its use, IDSA, Indian national guidelines, and certain states (KL, MH, MG and WB) have recommended its use in a select few cases.

\section{Convalescent plasma}

Convalescent plasma (CP) was postulated to act as a source of neutralising antibodies that can inhibit the replication of the virus. The data from retrospective, observational studies, showing benefit, provided the basis for prospective studies $(35,36)$. However, randomised control trials failed to show any benefit with convalescent plasma $(37,38)$. Libster et al. showed that early use of high-titre CP (within 72 hours) might halt the disease progression in elderly individuals (39). However, the use of CP within three days of onset in a high burden resource-limited setting is highly impractical. Besides, the results of the RECOVERY trial show that even high titre CP does not decrease mortality (40). Therefore, in accordance with the WHO and IDSA, the national guidelines have changed their stance on 17.05.21 and do not recommend CP in COVID-19. While most states recommend CP only in a trial setting, $\mathrm{KL}$ and $\mathrm{MH}$ continue to recommend $\mathrm{CP}$ as a part of clinical care in COVID-19.

\section{Inhaled steroids}

Owing to the remarkable success of systemic steroids, it was hypothesised that inhaled steroids might play a role in preventing progression when given early in course in patients with persistent symptoms. The two published, STOIC trial and PRINCIPLE trial showed a reduced time to recovery and reduced need for emergency care $(41,42)$. The WHO and IDSA do not make any recommendations on inhaled steroid use in COVID-19. However, inhalational budesonide has been recommended in mild illness with persistent symptoms by the national guidelines and KL state guidelines. 


\section{Anticoagulation}

Anticoagulation has been one of the critical pillars in moderate-severe disease management. Although their use in moderate to severe diseases is uniformly recommended, there is a lack of clarity on the dosing schedule (low-dose vs. intermediate/highdose prophylaxis or therapeutic anticoagulation). INSPIRATION trial in critically ill patients with COVID-19 showed no difference between standard vs. intermediate prophylactic dose of anticoagulation in terms of the composite outcome of thrombosis, treatment with extracorporeal membrane oxygenation, or mortality within 30 days (43). While the WHO and IDSA recommend using low dose anticoagulation for thromboprophylaxis, national and state guidelines have mentioned variable doses. Pooled analysis from three trials (REMAP-CAP, ACTIV-4a and ATTAC trials) show that although the incidence of thrombotic events is lesser in the therapeutic anticoagulation group, there was no difference in major thrombotic events and mortality (44). In another analysis, therapeutic doses of anticoagulation decreased the need for oxygen support in non-critically ill hospitalised patients (45). Only MP state guidelines mention therapeutic doses of anticoagulation but do not distinguish between critically and non-critically ill patients.

In summary, despite the lack of evidence, some guidelines continue to recommend HCQ, ivermectin, favipiravir and convalescent plasma. With regards to indication, dose and duration of steroids and anticoagulants, there was wide variability amongst the various guidelines. Many of the recommendations in the guidelines were only expert-based and sometimes even contradictory to the best available evidence. In addition to the massive spurt of cases in the second wave that hampered the access to quality care, the lack of concordance in guidelines might have added to the confusion. Therefore, there is a need to develop a unified living guideline for COVID management that is evidence-informed and beneficial in curbing the proportion of inappropriate prescriptions.

Funding: The views in this article are of the author's personal opinions and do not necessarily indicate the views of their institution.

Conflict of Interest: The authors have no conflicts of interest to disclose.

\section{References}

1. Kumar R, Vinod KS, Mittal A, Adhikari SD, Gupta N. Review of current clinical management guidelines for COVID-19 with special reference to India. Drug Discov Ther. 2020;14:171-176.

2. Geleris J, Sun Y, Platt J, Zucker J, Baldwin M, Hripcsak G, Labella A, Manson DK, Kubin C, BArr RG,
Sobieszczyk ME, Schluger NW. Observational study of hydroxychloroquine in hospitalised patients with Covid-19. N Engl J Med. 2020; 382:2411-2418.

3. Rosenberg ES, Dufort EM, Udo T, Wilberschied LA, Kumar J, Tesoriero J, Weinberg P, Kirkwood J, Muse A, DeHovitz J, Blog DS, Hutton B, Holtgrave DR, Zucker HA. Association of treatment with hydroxychloroquine or azithromycin with in-hospital mortality in patients with COVID-19 in New York state. JAMA. 2020; 323:2493-2502.

4. RECOVERY Collaborative Group, Horby P, Mafham $\mathrm{M}$, et al. Effect of hydroxychloroquine in hospitalised patients with Covid-19. N Engl J Med. 2020; 383:20302040.

5. WHO Solidarity Trial Consortium, Pan H, Peto R, et al. Repurposed antiviral drugs for Covid-19 - Interim WHO Solidarity trial results. N Engl J Med. 2021; 384:497511.

6. Boulware DR, Pullen MF, Bangdiwala AS, et al. A randomised trial of hydroxychloroquine as postexposure prophylaxis for Covid-19. N Engl J Med. 2020; 383:517525.

7. Skipper CP, Pastick KA, Engen NW, et al. Hydroxychloroquine in nonhospitalised adults with early COVID-19: A randomised trial. Ann Intern Med. 2020; 173:623-631.

8. Chaccour C, Casellas A, Blanco-Di Matteo A, et al. The effect of early treatment with ivermectin on viral load, symptoms and humoral response in patients with non-severe COVID-19: A pilot, double-blind, placebocontrolled, randomised clinical trial. EClinicalMedicine. 2021; 32:100720.

9. Babalola OE, Bode CO, Ajayi AA, Alakaloko FM, Akase IE, Otrofanowei E, Salu OB, Adeyemo WL, Ademuyiwa AO, Omilabu S. Ivermectin shows clinical benefits in mild to moderate COVID19: A randomised controlled double-blind, dose-response study in Lagos. QJM. 2021; hcab035.

10. Galan LEB, Santos NMD, Asato MS, et al. Phase 2 randomised study on chloroquine, hydroxychloroquine or ivermectin in hospitalised patients with severe manifestations of SARS-CoV-2 infection. Pathog Glob Health. 2021; 115:235-242.

11. López-Medina E, López P, Hurtado IC, et al. Effect of ivermectin on time to resolution of symptoms among adults with mild COVID-19: A randomised clinical trial. JAMA. 2021; 325:1426-1435.

12. Hill A, Abdulamir A, Ahmed S, Asghar A, Babalola OE, Basri R, Chaccour C, Chachar AZ, Chowdhury AT, Elgazzar A, Ellis L. Meta-analysis of randomised trials of ivermectin to treat SARS-CoV-2 infection. Open Forum Infect Dis. 2021; ofab358.

13. Cai Q, Yang M, Liu D, et al. Experimental treatment with favipiravir for COVID-19: An open-label control study. Engineering (Beijing). 2020; 6:1192-1198.

14. Doi Y, Hibino M, Hase R, et al. A prospective, randomized, open-label trial of early versus late favipiravir therapy in hospitalised patients with COVID-19. Antimicrob Agents Chemother. 2020; 64:e01897-20.

15. Udwadia ZF, Singh P, Barkate H, Patil S, Rangwala S, Pendse A, Kadam J, Wu W, Caracta CF, Tandon M. Efficacy and safety of favipiravir, an oral RNAdependent RNA polymerase inhibitor, in mild-to-moderate COVID-19: A randomised, comparative, open-label, multicenter, phase 3 clinical trial. Int J Infect Dis. 2021; 
103:62-71.

16. Dabbous HM, El-Sayed MH, El Assal G, Elghazaly H, Ebeid FFS, Sherief AF, Elgaafary M, Fawzy E, Hassani SM, Riad AR, TagelDin MA. Safety and efficacy of favipiravir versus hydroxychloroquine in management of COVID-19: A randomised controlled trial. Sci Rep. 2021; 11:7282.

17. Solaymani-Dodaran M, Ghanei M, Bagheri M, et al. Safety and efficacy of favipiravir in moderate to severe SARS-CoV-2 pneumonia. Int Immunopharmacol. 2021; 95:107522.

18. Khamis F, Al Naabi H, Al Lawati A, Ambusaidi Z, Al Sharji M, Al Barwani U, Pandak N, Al Balushi Z, Al Behrani M, Al Salmi I, Al-Zakwani I. Randomized controlled open label trial on the use of favipiravir combined with inhaled interferon beta- $1 \mathrm{~b}$ in hospitalised patients with moderate to severe COVID-19 pneumonia. Int J Infect Dis. 2021; 102:538-543.

19. Wang Y, Zhang D, Du G, et al. Remdesivir in adults with severe COVID-19: a randomised, double-blind, placebocontrolled, multicentre trial. Lancet. 2020; 395:15691578. Erratum in: Lancet. 2020; 395:1694.

20. Beigel JH, Tomashek KM, Dodd LE, et al. Remdesivir for the treatment of Covid-19 - final report. N Engl J Med. 2020; 383:1813-1826.

21. RECOVERY Collaborative Group, Horby P, Lim WS, Emberson JR, Mafham M, Bell JL, et al. Dexamethasone in hospitalised patients with Covid-19. N Engl J Med. 2021; 384:693-704

22. Edalatifard $\mathrm{M}$, Akhtari $\mathrm{M}$, Salehi $\mathrm{M}$, et al. Intravenous methylprednisolone pulse as a treatment for hospitalised severe COVID-19 patients: results from a randomised controlled clinical trial. Eur Respir J. 2020; 56:2002808.

23. Tomazini BM, Maia IS, Cavalcanti AB, et al. Effect of dexamethasone on days alive and ventilator-free in patients with moderate or severe acute respiratory distress syndrome and COVID-19: The CoDEX randomized clinical trial. JAMA. 2020; 324:1307-1316.

24. Angus DC, Derde L, Al-Beidh F, et al. Effect of hydrocortisone on mortality and organ support in patients with severe COVID-19: The REMAP-CAP COVID-19 corticosteroid domain randomized clinical trial. JAMA. 2020; 324:1317-1329.

25. Tang X, Feng YM, Ni JX, et al. Early use of corticosteroid may prolong SARS-CoV-2 shedding in non-intensive care unit patients with COVID-19 pneumonia: A multicenter, single-blind, randomized control trial. Respir Int Rev Thorac Dis. 2021; 100:116-126.

26. Corral-Gudino L, Bahamonde A, Arnaiz-Revillas F, et al. Methylprednisolone in adults hospitalised with COVID-19 pneumonia: An open-label randomised trial (GLUCOCOVID). Wien Klin Wochenschr. 2021; 133:303-311.

27. Yang Z, Liu J, Zhou Y, Zhao X, Zhao Q, Liu J. The effect of corticosteroid treatment on patients with coronavirus infection: a systematic review and meta-analysis. J Infect. 2020; 81:e13-20.

28. Stone N, Gupta N, Schwartz I. Mucormycosis: time to address this deadly fungal infection. Lancet Microbe 2021. https://www. thelancet.com/journals/lanmic/ article/PIIS26665247(21)00148-8/fulltext (17 June 2021, date last accessed).

29. Singh AK, Singh R, Joshi SR, Misra A. Mucormycosis in COVID-19: A systematic review of cases reported worldwide and in India. Diabetes Metab Syndr. 2021;
15:102146.

30. Guaraldi G, Meschiari M, Cozzi-Lepri A, et al. Tocilizumab in patients with severe COVID-19: a retrospective cohort study. Lancet Rheumatol. 2020; 2:e474-e484.

31. Biran N, Ip A, Ahn J, et al. Tocilizumab among patients with COVID-19 in the intensive care unit: a multicentre observational study. Lancet Rheumatol. 2020; 2:e603612.

32. Salama C, Han J, Yau L, et al. Tocilizumab in patients hospitalised with Covid-19 pneumonia. N Engl J Med. 2021; 384:20-30.

33. Soin AS, Kumar K, Choudhary NS, et al. Tocilizumab plus standard care versus standard care in patients in India with moderate to severe COVID-19-associated cytokine release syndrome (COVINTOC): an open-label, multicentre, randomised, controlled, phase 3 trial. Lancet Respir Med. 2021; 9:511-521.

34. RECOVERY Collaborative Group. Tocilizumab in patients admitted to hospital with COVID-19 (RECOVERY): a randomised, controlled, open-label, platform trial. Lancet Lond Engl. 2021; 397:1637-1645.

35. Xia $\mathrm{X}, \mathrm{Li} \mathrm{K}, \mathrm{Wu} \mathrm{L}$, et al. Improved clinical symptoms and mortality among patients with severe or critical COVID-19 after convalescent plasma transfusion. Blood. $2020 ; 136: 755-759$.

36. Abolghasemi H, Eshghi $\mathrm{P}$, Cheraghali AM, et al. Clinical efficacy of convalescent plasma for treatment of COVID-19 infections: Results of a multicenter clinical study. Transfus Apher Sci. 2020; 59:102875.

37. Li L, Zhang W, Hu Y, et al. Effect of convalescent plasma therapy on time to clinical improvement in patients with severe and life-threatening COVID-19: A randomised clinical trial. JAMA. 2020; 324:460-470.

38. Agarwal A, Mukherjee A, Kumar G, Chatterjee P, Bhatnagar T, Malhotra P; PLACID Trial Collaborators. Convalescent plasma in the management of moderate covid-19 in adults in India: open label phase II multicentre randomised controlled trial (PLACID trial). BMJ. 2020; 371:m3939.

39. Libster R, Marc GP, Wappner D, et al. Early high-titer plasma therapy to prevent severe Covid-19 in older adults. N Engl J Med. 2021; 384:610-618.

40. Abani O, Abbas A, Abbas F, et al. Convalescent plasma in patients admitted to hospital with COVID-19 (RECOVERY): a randomised controlled, open-label, platform trial. Lancet. 2021; 397:2049-2059.

41. Ramakrishnan S, Nicolau DV, Langford B, et al. Inhaled budesonide in the treatment of early COVID-19 (STOIC): a phase 2, open-label, randomised controlled trial. Lancet Respir Med. 2021; 9:763-772.

42. Yu LM, Bafadhel M, Dorward J, et al. Inhaled budesonide for COVID-19 in people at high risk of complications in the community in the UK (PRINCIPLE): a randomised, controlled, open-label, adaptive platform trial. Lancet. 2021; S0140-6736(21)01744-X.

43. INSPIRATION Investigators, Sadeghipour P, Talasaz $\mathrm{AH}$, et al. Effect of intermediate-dose vs standard-dose prophylactic anticoagulation on thrombotic events, extracorporeal membrane oxygenation treatment, or mortality among patients with COVID-19 admitted to the intensive care unit: The INSPIRATION randomized clinical trial. JAMA. 2021; 325:1620.

44. Remap-Cap T, ACTIV-4a, Investigators A, Zarychanski R. Therapeutic anticoagulation in critically ill patients 
with Covid-19 - Preliminary report. medRxiv. 2021; 2021.03.10.21252749.

45. The ATTACC A-4a, Lawler PR, Goligher EC, et al. Therapeutic anticoagulation in non-critically ill patients with Covid-19. medRxiv. 2021; 2021.05.13.21256846.

Received June 21, 2021; Revised August 16, 2021; Accepted August 22, 2021

\section{*Address correspondence to:}

Nitin Gupta, Department of Infectious Diseases, Kasturba Medical College, Manipal, Manipal Academy of Higher Education, Manipal, Karnataka-576104, India.

E-mail: nityanitingupta@gmail.com

Released online in J-STAGE as advance publication August 26, 2021. 